\title{
Pediatric Viral Infection
}

National Cancer Institute

\section{Source}

National Cancer Institute. Pediatric Viral Infection. NCI Thesaurus. Code C96411.

A viral infection that occurs during infancy, childhood or adolescence. 